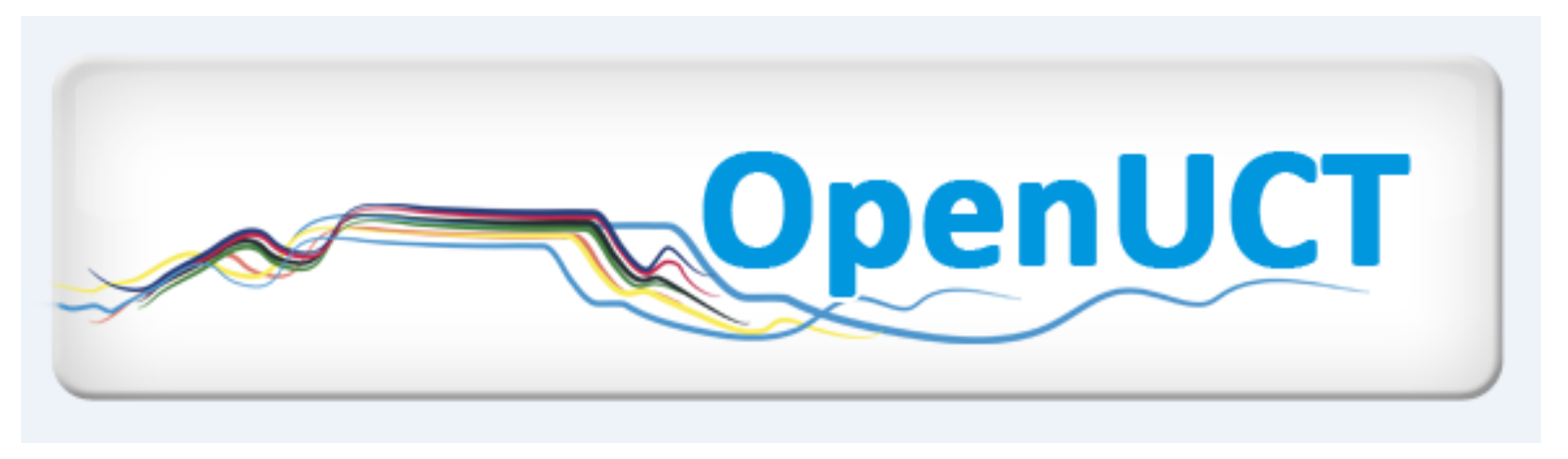

This is the post-print of McMillan, J. 2011. What happens when the university meets the community? Service learning boundary work and boundary workers. Teaching in Higher Education. 16(5): 553-564. DOI: 10.1080/13562517.2011.580839.

It is made available according to the terms of agreement between the author and the journal, and in accordance with UCT's open access policy available:

http://www.openuct.uct.ac.za/sites/default/files/UCTOpenAccessPolicy.pdf, for the purposes of research, teaching and private study. 


\title{
What happens when the university meets the community? Service learning, boundary work and boundary workers
}

\author{
Janice McMillan: University of Cape Town, Cape Town, South Africa.
}

\begin{abstract}
This article explores service learning via the lens of activity theory. Through this lens, it is identified as a form of 'boundary work' in higher education, with educators identified as 'boundary workers'. Drawing on the data from a recent study, this paper analyses service learning as an often contradictory and tension filled practice. The 'expanded community' and 'dual but interrelated object' in the service learning activity system result in many tensions for students and community members alike. This in turn poses significant challenges for boundary workers, and ultimately for the university. The paper concludes by arguing that in order to encourage and value service learning, we need to acknowledge the (new and different) knowledge, values and skills required for playing the role of boundary worker in (boundary) practices such as this.
\end{abstract}

Keywords: service learning; activity theory; boundary work; boundary workers; contradictions

Boundary work needs to be facilitated and managed and to do this specific knowledge and skills are required . . . engagement as a core value will be evident in the extent to which universities do actually develop the skills, create the organisational forms and manage tensions that will inevitably arise when different social worlds interact. [T]o embrace this form of engagement entails that universities themselves be prepared to participate in those potential transaction spaces in which complex problems and issues will be initially and tentatively broached (Gibbons 2005, 11Á12).

\begin{abstract}
We] have to be better interpreters in order to negotiate . . . the expectation is that facilitators need to be adequately skilled to address all of those shifts in spaces and discourses and all the interpretations that need to be happening (Anna, communitybased site facilitator at University of Cape Town (UCT), Interview 9 November 2004; emphasis added).
\end{abstract}

\section{Introduction and background context}

Michael Gibbons (2005) has spoken about the need to re-imagine the relationship between higher education and society and he calls for the emergence of a 'new social contract'. In order for the social contract to develop, he highlights the importance of understanding what he calls new 'transaction spaces' or 'boundary zones' in which new relationships are developed. In a recent study (McMillan 2008), I sought to better understand service learning, or community-based learning as a 'boundary' practice. Very little service learning research has focused on better understanding 
'what happens' when students and community members engage together in projects, or what theoretical and conceptual frames we can use to analyse such (joint) practices.

It is here that my paper is located Á developing a lens to conceptualise service learning as a form of 'boundary work' in higher education. To do this, I used activity theory (Engestrom 1996) to analyse two service learning courses as activity systems" at the boundary between two communities of practice (Lave and Wenger 1991) Á the university and the community Á filled with tensions and contradictory impulses. Such tensions are evident in the experiences of the two 'boundary workers' or educators in the courses.

\section{The research study}

By the nature of the questions and issues that guided my thinking, I was drawn to undertaking a qualitative study. Such 'interpretive' studies are designed to 'investigate human experience and to do so in ways that both reveal its complexity and reflect its historical and situational contexts' (Maclean 1987, 132). Interpretivists are therefore concerned with 'subjectivity', with 'understandings', with 'agency' and the way people construct their social world (Grix 2001).

My study asked the question: what happens when the university meets the community? I wished to observe what students and community members 'did' or 'practised' together in their service projects. In addition, I was interested in understanding the role of educators and how they work at the boundary between higher education and the community in which the service learning takes place. What roles do they play, and how do they play them? The two service learning programmes I looked at during the 2004Á2005 academic years were based at UCT. One was in Primary Health Care/Public Health and the other in Environmental and Geographical Science.

A brief point about research ethics and anonymity before continuing. I discussed these issues with the research ethics committee in the case of the Primary Health Care Department and with the Head of Department in the case of Environmental and Geographical Sciences (EGS), as well as with each of the boundary workers. Both departments were more than happy with their identities being revealed, as were the two boundary workers. However, in the end we agreed that while I would identify the departments and university, I would use pseudonyms for 'Anna' and 'Susan'. In terms of the community partners, I likewise used the real names of the organisations but pseudonyms for the people involved.

The fourth year Bachelor of Medicine, Bachelor of Surgery (MBChB) Primary Health Care/Public Health community-based block is a compulsory block offered by the School of Public Health and Family Medicine within the Faculty of Health Sciences at UCT. It is a compulsory part of the degree students take when qualifying as medical doctors in South Africa. The MBChB is an undergraduate degree over six years, including a seventh year of internship to qualify. This block comprises eight weeks in which students are on site in the community three to four days per week. In the particular project I observed, students were engaged in a project with the South African Domestic Servants and Allied Workers Union (SADSAWU). The project with SADSAWU was on occupational health and safety: the students undertook research on the health and safety conditions under which the workers work, 
presented these results to the union, and ran a workshop with union members based on their findings.

The second case study involved third year human geography students in a research and mapping project with a community-based organisation in Valhalla Park (a neighbourhood of Cape Town), the Valhalla Park United Civic Front organisation (VPUCF), a community-based organisation working for social change particularly around housing. This case involved an introduction to the Valhalla Park community, research aimed at collecting data (quantitative and qualitative) on the lives of people living in backyard shacks, 1 and a presentation to Civic members. The students went on four site visits where they worked with the Civic and the data collected contributed to the Civic's negotiations with the City for better housing.

In both cases, my main data sources were:

- 'thick' field notes observing student activities in the field. In the MBChB case this was limited to the meeting with the unions, i.e. it did not include the interviews with the domestic workers as it was felt to be too intrusive to have me there. In the EGS case, I went into the field with the students on their site visits. In both cases, my involvement with the course stretched over a 2 Á3month time period;

- interviews with academics and educators involved in the two courses;

- interviews with community members (more informally); and

- student reflective journals.

In each case, I identified the educator who worked with both the students and the community members. I called her a 'boundary worker' as I began to understand that the work of such educators is important 'boundary mediation' work. In the MBChB case, the boundary worker was 'Anna' who was employed by the Health Sciences Faculty as a site facilitator and who initiated the projects as well as working with the students in the field. Anna has a background in adult education, and community health. In the EGS case, this role was taken on by 'Susan', an academic in the field of urban and human geography, who also has a long history of engagement with the Civic in their struggles over housing.

\section{Understanding service learning as an activity system}

Service learning has been variously defined and linked to other educational practices such as volunteerism, co-operative education, internships and community outreach. However, it is clear from reading the service learning literature that understanding this form of educational practice often involves understanding a bigger picture: a range of complex and challenging relationships, processes and interactions that go beyond what we would understand as the formal curriculum in higher education (Cruz and Giles 2000; Stanton, Giles, and Cruz 1999). As a way into understanding such processes, a number of authors have explored service-learning as a form of 'border pedagogy' (Hayes and Cuban 1997; Keith 1998; Skilton-Sylvester and Erwin 2000; Taylor 2002), drawing largely on work in critical pedagogy and critical postmodernism (Anzaldua 1987; Giroux 1992). All of them argue that we need to develop new lenses to understand aspects of the service-learning experience. They argue that the metaphors of 'borders', 'border-crossing' and 'borderland' are useful 
and important as a 'compelling starting point for describing and rethinking the nature of service-learning' (Hayes and Cuban 1997, 74).

By focusing my research on the universityÁcommunity interface or the boundary zone, I set out to develop a frame to analyse my data which extends the borderland metaphor above.

\section{Situated learning and communities of practice}

Given my understanding, following Vygotsky (1978), that learning happens first in the social and then in the individual plane, i.e. is an inherently social practice, I have long been drawn to theories that focus on learning as social practice. 2 In particular, I found Lave and Wenger's (1991) concept of 'community of practice' a useful start. Because it used to refer to the sustained engagement with others in (similar or related) practices over time, I understand academic disciplines, professional discipline-related bodies on the one hand, and community organisations and activities/practices, on the other, as communities of practice, each with their particular practices and ways of doing things. 3

While situated learning has a lot to offer and has been drawn on in theorising service learning (Castle, Osman, and Henstock 2003; Wolfson and Willinsky 1998), it also has limitations (Daniels 2001; Hay 1993; Hodges 1998). These include a lack of a coherent account of contexts that shape learning, thereby weakening it as a tool to use in exploring different communities of practice as they interact with others in a new setting. Many argue that a situated learning lens also does not directly and explicitly develop a theory of power and power relations (Cooper 2005; Hodges 1998; Hodkinson and Hodkinson 2003).

\section{Activity theory: delineating the 'unit of analysis'}

To address these critiques I returned to the roots of situated learning and to the work of a number of post-Vygotskians. I drew on activity theory (Engestro 1993, 1996;"m Engestro and Miettinen 1999) in particular, where the unit of analysis is the activity"m system. I used activity theory to 'focus on how situational factors shape human actions (e.g. Engestrom 1993) . . . in particular, [to] delineat[e] what comprises a social" practice and identifying the factors that constitute that practice' (Billett 2002, 85; my emphasis). Through this lens, learning, teaching and service can thus be viewed as activities that involve people and objects interacting in complex ways.

Engestrom (1999 in Daniels 2001, 91) argues that we also need to take into" account that activity systems are inherently contradictory and conflictual. 'Instability, contradictions and tensions' are the motive force behind change and development. Thus within one activity system there are inherent contradictions, e.g. between community and object, between tool and division of labour or between tool and rules. It is the resolution of such tensions that leads to change and therefore development.

Barab et al. (2002) draw on activity theory to understand the 'systemic tensions' in an astrology course. The authors argue that activity theory is a useful means to analyse participation by students and teachers in the course, highlighting the 'nested instances of activity' that characterised the course dynamics. In describing these dynamics, the researchers show the historical development and changes that the 
course went through. The tools of activity theory highlight the 'course-in-themaking' rather than the 'ready-made' course. In addition, the authors argue we need to understand that components of activity systems are not static components existing in isolation, but are dynamic and interact continuously with other components. The authors draw on an example to illustrate this point:

\begin{abstract}
Activity systems are characterised by their internal contradictions ... These ... are best understood as tensions among the components of the activity system. For example, in school learning there is a pervasive tension between learning the material to receive a grade (what Lave 1993 described as the 'exchange value' of what is learned) and learning material because of its importance in addressing real-world problems (what Lave described as the 'use value'). Tensions are critical to understanding what motivates particular actions and in understanding the evolution of a system more generally ... As tensions enter the systems they become the moving force behind disturbances and innovations and eventually drive the system to change and develop (Barab et al. 2002, 79Á80).
\end{abstract}

Following Engestrom (1996), there are 'three generations' of activity theory. In the" first generation activity theory there are three essential elements: subject/s, object/s and tools. The subjects are individuals or subgroups engaged in an activity (e.g. students). The object is the 'raw material' on which the subject brings to bear various tools, e.g. the 'object of study' (e.g. learning about a topic, doing community service). In any activity system, the motive is linked to 'object' as it shapes the outcome of the activity's overall. Tools, both material and/or conceptual (Cole 1996), are understood as things that mediate subjects' action upon objects, i.e. they mediate or facilitate subjects doing things (e.g. a concept, a computer or a text).

For the second generation, Engestrom expands the framework to examine" systems of activity at the macro level. The importance of this shift is that it foregrounds interrelations between the individual subject and his/her community of which he/she was a member. The community is the broader or larger group interacting in the activity and of which the subject/s is a part (e.g. students and educators). The division of labour refers to the power relations and different roles that are evident in an activity, often causing contradictions in the system. The rules operating in any activity are broadly understood as not only formal and explicit rules governing behaviour but, also those that are 'unwritten and tacit', often referred to as norms, routines, habits, values and conventions (Engestrom 1996; Russell 2002). I" have used them to refer to Discourse (Gee 1990). Figure 1 captures such a system below.

Finally, the third generation activity theory is aimed at providing tools and concepts that can enable us to understand and explore multiple viewpoints, value systems and 'networks of interacting activity systems' (Daniels 2001, 91; emphasis added) whereby contradictions highlighted by contested activity system objects emerge.

While I was influenced by the third generation activity theory, I understand service learning as two communities of practice interacting via one activity system and engaged in joint activities (McMillan 2008). They are an activity system only when engaging with an outside community of practice, i.e. it is only at the intersection with each other, that these communities of practice become one system and through their activities together, the elements of the system get constituted. The 


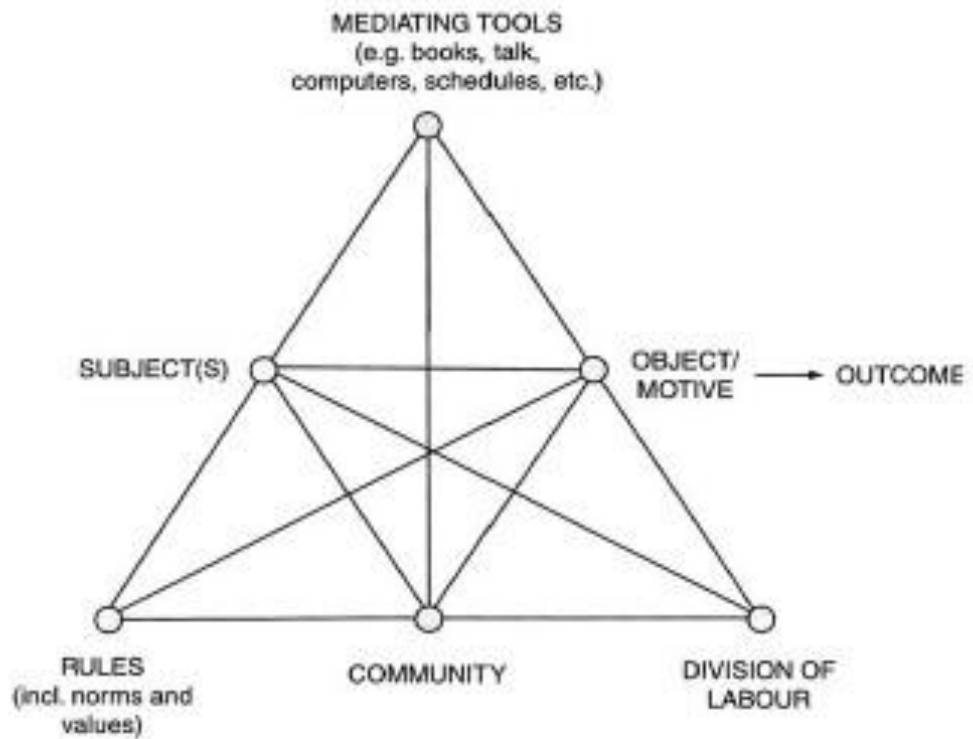

Figure 1. An activity system. See Russell, 2002, p. 68.

activity system does not exist outside of the service learning activities. The 'boundary zone' thus reflects the activity system representing the service learning project, i.e. the unit of analysis. As a result of this, I focused on using the second generation activity theory in my study (see Figure 1).

\section{Mediating contradictions: educators as 'boundary workers'}

Lastly, I identified the educators as 'brokers' (Wenger 1998) or 'boundary workers' as I prefer to call them: agents who assist participants make new connections across communities of practice, enable co-ordination and, if experienced, open new possibilities for meaning and therefore learning (Wenger 1998). According to Wenger, 'boundary work' is a complex role as it involves 'processes of translation, coordination and alignment between perspectives'. In order to influence the development of a practice, to mobilise attention and to address conflicting interests Á in other words, to assist with learning by introducing elements of one activity system into another Á requires legitimation on both sides of the boundary, i.e. within the university and the community. This raises important questions for us in service learning. Can educators (and students) cope with the new norms and values brought in by the (outside) community in this new form of pedagogy, e.g. with a new emphasis on experiential learning? What happens to the division of labour when educators start working and learning with community members? What knowledge, values and skills are needed to negotiate the boundary zone? The next section discusses the analysis of the two cases in which I address some of these questions.

\section{Service learning as boundary work}

In each case, I identified three 'nested' or linked activities that make up a system, i.e. that constitute the system object (Yamagata-Lynch 2003). These included the initial meeting and planning session, the field work or data collection, and the final presentation of findings to the community. Together these constituted my unit of 
analysis. I then identified contradictions within each activity in each of the two cases, before looking across the three nested activities at the 'activity system' level in each case. This analysis is then informed my findings and conclusion.

As a way into the analysis, let me provide data 'snapshots' from the two cases. Both are taken from my fieldwork notes: the first from the MBChB case where I observed the final workshop the students ran for the domestic workers (nested activity 3 ) and the second from an EGS student's journal in which she describes a contradiction in her fieldwork experience (nested activity 2):

The whole workshop then took another turn when one of the domestic workers started acting out. A volunteer worker was asked for by student $\mathrm{H}$ to demonstrate picking up a basket to see whether they were doing 'it correctly'. One of the workers then exaggerated the role of picking up a basket and made fun of the role-play including the student who was running it. Student $\mathrm{H}$, a male student, then started demonstrating another role-play on ironing, showing the technique. While this is going on, [a domestic worker] gets up to do a little ironing skit in the corner. One of the other domestic workers said, as if she felt sorry for the student 'ok, I get your point, wow!' Felicia [one of the workers] then said that picking up a basket is difficult Á for the 'fuller person Á she can go halfway down but I am not sure if she can come up again!' One of the other domestic workers put it like this: 'jou maag kom in tussen jou bene [your stomach comes in between your legs] Á ok, then you must tuck your tummy in'. There was laughter from both students and workers (Field notes, 17 October 2004).

Today our partners and ourselves met with our assigned activist and we started the survey process in our designated area, ours being area 2. Our guide's name was Den ... we did a total of 16 surveys. At first I found it a bit awkward asking people the survey questions ... not being accustomed with performing interviews, it felt somewhat imposing. I felt especially uncomfortable asking whether or not the backyarders used a bucket or pit toilet. My partner felt the same so after the first interview we decided to leave those questions out as the previous question on whether everyone used the inside toilet, seemed to be sufficient (Student D1, Journal entry 26 July).

Service learning as a social practice reflects multiple tensions and contradictions as a result of specific features of the practice made visible by an activity theory lens (McMillan 2008). Firstly, service learning shifts the notion of 'community' compared with a traditional course. I have called this an 'expanded community', i.e. not just students and educators as the community in the system but an outside community as well. Secondly, there is what I have called a dual but interrelated object Á both a (student) learning and (community) service object. These two features result in tensions and contradictions in the service learning activity system between the rules, tools and division of labour.

In particular, my data revealed that this can lead to students and their community partners challenging the tools in the activities, with an impact on the division of labour. This happened in different ways in each course as illustrated in the examples above. In the EGS course, the Civic had a big stake in the questionnaire, the primary tool in the mapping exercise. They had designed it themselves the previous year to use for their own ends. In their service learning, the students were asked to administer it; they thus had no choice over the questions to ask. Many of the challenges emanated from questions which the students refused to ask, e.g. whether residents had a toilet in their backyard shacks or not. This is critical information for the Civic but difficult for many white, middle-class students to ask. As a consequence, a few of them simply 
left the question out. This provides a challenge to the tool of the system and indicates the impact of introducing an expanded community into the activity system. It also provides a challenge to the boundary worker in helping the student make sense of this apparent contradiction.

In the MBChB case, there was a challenge over tools as well. The particular example provided was the final system activity, the primary health care workshop on occupational health and safety designed by the students based on the findings of their epidemiological research. As a tool of mediation, the workshop was more familiar to the workers than the students who were running it; as we saw, the workers thus found ways of challenging it by joining in activities before they were asked to. The challenge for the boundary worker is to use this incident to teach students about how knowledge resides in many places besides their formal curriculum, and how students need to value the knowledge of domestic workers in future. The key question is: what does it take for boundary workers to make use of such moments?

\section{The role of boundary workers: identity in social practice}

Boundary work is a complex role Á it is more than translation (as Anna alluded to at the beginning of the paper). To do the work well, requires influencing the development of a practice and addressing conflicting interests, i.e. to assist with learning by introducing elements of one community of practice into another. To do this requires understanding the different communities of practice you are working across. Roles (and the identities they create), are therefore a dimension of specific social practices with histories and rules. In this case, of the university and a specific community or group outside the university.

Others have noted the social dimension of identity and its impact on roles. Holland et al. (1998) argue that identities 'are lived in and through activity and so must be conceptualised as they develop in social practice' $(1998,5)$. In order to understand identities and agency, we need therefore to focus on 'the development of identities and agency specific to practices and activities situated in historically contingent, socially enacted, culturally constructed "worlds"' $(1998,7)$.

The role of boundary workers is thus developed at the intersection of practice and identity; in order to have agency, you need to understand the practice, and have power within it. However, because boundary workers need to address often conflicting interests of more than one community of practice, they need to carefully manage the 'co-existence of membership and non-membership' of particular communities of practice (Wenger 1998, 110). This means that they are both 'in' and 'out' of the practices simultaneously, which can result in them feeling individually inadequate in their roles and lacking credibility and power. The cases of Anna and Susan speak to these issues in different ways.

\section{Anna as 'activist educator'}

Anna was a university-based and paid community site facilitator who worked with the MBChB students on their service learning projects largely due to her background in working with other community organisations in an education and research role. She says site facilitators: 
... need to be up-dated [sic] with the debates in how you need to understand what [. . .] research requires of the student. You need to be able to speak in the [university] environment and the community environment. You need to understand project planning and how to guide students through the project planning. You need to know what it means for the project if you do or don't secure certain things, and you won't unless you have a little bit of an understanding of research methodology (Interview, 9 November 2004).

Anna understands that she needs insight into more than one community of practice to work at the boundary but notes that this is complex:

Different students will take on different values or not within that discourse and change their discourse accordingly or not, depending on how possible it is for them to be a flexible learner, or how secure they can be in that identity ... I sometimes caution myself [that] you can't change them into activists because it is damaging to do something like that when they have to go into the next block and be the kind of learner that they have to be in the rest of the curriculum, a kind of learner that has to accept that they are experts and that you don't question certain things. If we are schooling them to become questioners and challengers in this block it is really damaging to them in the rest of their studies when it doesn't get valued there and they get victimized for being that kind of person/learner. The goal is huge (Anna, Interview 9 November 2004).

Despite these skills and insight, site facilitators are not considered 'academics' (Cooper 2001) thereby diminishing their agency in the university. Anna argues that she sees herself more as an educator than an academic, an identity not much valued in higher education:

Education as such is not really something that a lot of academics are trained in. They are specialists in the area but they have never really had training as educators whereas it seems like all the site facilitators have an adult education training (Interview, 9 November 2004).

Anna does not have the power and credibility that discipline-based academics do on the university side of the boundary, e.g. she was not always able to challenge the students on their viewpoints or conclusions in their papers. This was left to the 'academic' in the course, in this case, the epidemiological supervisors who graded the final papers. However the supervisor was not present at any of the off-campus activities. All this causes a tension in her role:

In the university I get a sense, and I don't know how right I am, that the site facilitators are very much considered community/field workers [however] the community perceives me as a member of the university (Interview, 9 November 2004).

\section{Susan as 'activist academic'}

The case of Susan is quite different. Unlike Anna who played a more direct facilitating role in the activities, Susan played more of an observer role once the EGS students are out in the field. She allowed the Civic members to guide the students and advise them. However she was also very present: she knows both the community and the university and so is able to be both a strong and credible presence in the community. She is also a relatively young but well respected academic. 
For Susan her involvement with the Civic is very intentional and linked to her long experience in both activism and academe, a link she believes is critical, e.g. she makes very clear to students that:

communities have all sorts of knowledge and that knowledge is all over the place ... knowledge is not [just] something that's found up here . . . [at the university] (Interview, 15 October 2005).

This approach was evident in her teaching with the students. She made it clear that the questionnaire instrument was the Civic's and therefore they (the students) needed to ask all the questions on it, despite their personal reluctance to do so. Susan is also perceived by her students as having the experience to deal with this course and they value her insight:

\begin{abstract}
She is not just being an academic; she is really going out there and dealing with communities that are struggling and making them feel a lot better and giving them a lot more hope and drawing them into her life making them feel that they are a part of her life (Student D1, interview 19 January 2006).
\end{abstract}

Susan believes her teaching practice and identity is enhanced through working and learning with off-campus communities and her engagement and relationships with these communities not only inform her research but serve to sustain relationships critical to her practice (Oldfield 2007). Susan thus has an agency on both sides of the boundary: as an 'academic' in the university and as an activist/researcher in the community. Working at the boundary enhances her agency in both realms. As a result of this, her role and authority as a boundary worker in the context of service learning is substantially enhanced.

What these two vignettes indicate is that roles and identities are complex, historical and linked to specific practices and contexts. This in turn impacts on the degree of agency one has in occupying a specific role, or taking on a specific identity:

[o]ne can never inhabit a world without at least the figural presence of others, of a social history in person. The space of authoring, of self-fashioning, remains a social and cultural space, ... [A]nd, it remains, more often than not, a contested space, a space of struggle ...' (Holland et al. 1998, 282).

In the case of boundary workers, this role will remain contested and a site of struggle until the university begins to recognise that the knowledge, skills and values required to do boundary work Á tied up as they are in social and historical practices Á are different from those for traditional academic scholarship.

\title{
Conclusion
}

This paper set out to analyse what happens when the university meets the community through a service learning course (understood as a form of social practice). Drawing on activity theory, I argued that in order to make sense of this practice, we need to shift our unit of analysis from individualised practices towards the transaction/ boundary zone and the social and contested practices that take place here between very different constituencies Á the university and the communities with which it is 
engaged. By looking at the experiences of educators as 'boundary workers', I argue that we need to acknowledge the conflicting and often contradictory nature of this role, and how it impacts on agency. If we are serious about developing new teaching and learning practices such as service learning, we need to start re-assessing the skills, knowledge and values that are required Á as academics and educators Á to be successful in this boundary worker role. Universities, if they are to serve as 'boundary institutions' (Hall 2003) and contribute to the public good, need to take up this challenge Á and soon.

\section{Notes}

1. The term 'backyard shack' is one of many (e.g. bungalow, Wendy house) used to describe the houses erected in the yards behind the more formal houses in a community like this. This is a widespread practice in South Africa where there are still massive housing shortages and can be seen in many communities.

2. I must note that my thesis did not focus on student learning per se; rather, I looked at learning to understand the social practices and activities between students and communities as they engaged with each other.

3. People are members of multiple communities of practice; however, I was looking specifically at the students in their discipline-based communities, and the community as activists engaging the students.

\section{References}

Anzaldua, G. 1987. Borderlands/la frontera: The new mestiza. San Francisco: Aunt Lute Books.

Barab, S.A., M. Barnett, L. Yamagata-Lynch, K. Squire, and T. Keating. 2002. Using activity theory to understand the systemic tensions characterising a technology-rich introductory astronomy course. Mind Culture and Activity 9, no. 2: 76Á107.

Billett, S. 2002. Workplaces, communities and pedagogies: An activity theory view. In Distributed learning: Social and cultural approaches to practice, ed. M. Lea and K. Nicholl, 83Á97. London, New York: Routledge and Open University Press.

Castle, J., R. Osman, and V. Henstock. 2003. Coupling 'school experience' with community service: A case study. Education as Change 7, no. 1: 3Á20.

Cole, M. 1996. Cultural psychology: A once and future discipline. Cambridge, MA: Harvard University Press.

Cooper, L. 2001. Report on research and 'recognition of prior learning' project with site facilitators of the primary health department. Unpublished report, University of Cape Town.

Cooper, L. 2005. Towards a theory of pedagogy, learning and knowledge in a trade union context: A case study of a South African trade union. PhD diss., University of Cape Town.

Cruz, N., and D. Giles. 2000. Where's the community in service-learning research? Michigan Journal of Community Service Learning (Special Issue Fall): 28 Á34.

Daniels, H. 2001. Vygotsky and pedagogy. London, New York: Routledge/Falmer.

Engestrom, Y. 1993. Development studies of work as a testbench of activity theory: The" case of primary care medical practice. In Understanding practice: Perspectives on activity and context, ed. S. Chaiklin and J. Lave, 64Á103. Cambridge: Cambridge University Press.

Engestrom, Y. 1996. Perspectives on activity theory. Cambridge: Cambridge University“ Press.

Engestrom, Y., and R. Miettinen. 1999. Introduction. In Perspectives on activity theory, ed." Y. Engestrom, R. Miettinen, and R.L. Punamaki, 1Á16. Cambridge: Cambridge University“ Press.

Gee, J. 1990. Social linguistics and literacies: Ideology in discourses. London: Falmer. 
Gibbons, M. 2005. Engagement with the community: The emergence of a new social contract between society and science. Paper presented at the Griffith University Community Engagement workshop, March 4, South Bank campus, Queensland.

Giroux, H. 1992. Border crossings: Cultural workers and the politics of education. New York: Routledge.

Grix, J. 2001. Demystifying postgraduate research: From MA to PhD. Edgbaston: Birmingham University Press.

Hall, M. 2003. Boundary institutions: Universities and social change. Discussion paper, University of Cape Town.

Hay, K. 1993. Legitimate peripheral participation, instructionism, and constructivism: Whose situation is it anyway? Educational Technology 33, no. 3: 33Á8.

Hayes, E., and S. Cuban. 1997. Border pedagogy: A critical framework for service-learning. Michigan Journal of Community Service-learning 4: 72Á80.

Hodges, D. 1998. Participation as dis-identification with/in a community of practice. Mind. Culture and Activity 5, no. 4: 272Á90.

Hodkinson, H., and P. Hodkinson. 2003. Rescuing communities of practice from accusations of idealism: A case study of workplace learning for secondary school teachers in England. Proceedings of Experiential: Community: Work-based: Researching learning outside the academy Conference, June 27Á29, in Glasgow.

Holland, D., W. Lachicotte Jr., D. Skinner, and C. Cain. 1998. Identity and agency in cultural worlds. Cambridge, MA: Harvard University Press.

Keith, N. 1998. Community service for community building: The school-based service corps as border crossers. Michigan Journal for Community Service-learning 5: 86 Á96.

Lave, J., and E. Wenger. 1991. Situated learning: Legitimate peripheral participation.

Cambridge: Cambridge University Press.

Maclean, H. 1987. Linking person-centred teaching to qualitative research training. In Appreciating adults' learning: from the learners' perspective, ed. D. Boud and V. Griffin, 127Á 36. London: Kogan Page.

McMillan, J. 2008. What happens when the university meets the community? An analysis of service learning as 'boundary work' in higher education. PhD diss., University of Cape Town.

Oldfield, S. 2007. Making sense of multiple conversations: Research, teaching and activism in and with 'communities' in South Africa cities. South African Geographical Journal 32, no. 2: 269 Á85.

Russell, D. 2002. Looking beyond the interface: Activity theory and distributed learning. In Distributed learning: Social and cultural approaches to practice, ed. M. Lea and K. Nicoll, 64Á82. London, NY: Routledge Falmer and Open University Press.

Skilton-Sylvester, E., and E. Erwin. 2000. Creating reciprocal learning relationships across socially-constructed borders. Michigan Journal of Community Service-learning (Fall): 65Á75.

Stanton, T., D. Giles, and N. Cruz. 1999. Service-learning: A movement's pioneers reflect on its origins, practice, and future. San Francisco: Jossey-Bass.

Taylor, J. 2002. Metaphors we serve by: Investigating the conceptual metaphors framing national and community service and service-learning. Michigan Journal of Community Service-Learning 9, no. 1: 45Á57.

Vygotsky, L.S. 1978. Mind in society. Cambridge, MA: Harvard University Press.

Wenger, E. 1998. Communities of practice: Learning, meaning and identity. Cambridge:

Cambridge University Press.

Wolfson, L., and M. Willinsky. 1998. What service-learning can learn from situated learning. Michigan Journal of Community Service-Learning 5: 22 Á31.

Yamagata-Lynch, L. 2003. Using activity theory as an analytic lens for examining technology professional development in schools. Mind. Culture and Activity 10, no. 2: 100Á19. 